\title{
Cognitive Effects in the Relationship between Budgetary Participation and Job Performance: A Case Study of Manufacturing Industry in Banten, Indonesia
}

\author{
Imam Abu Hanifah
}

\begin{abstract}
The study focused on budgetary participation in manufacturing companies in Banten Province, Indonesia. The purpose of the study is to find empirical evidence on the cognitive effects of information acquired by local managers related to budgetary participation and job performance. The method of the study is survey method. The sample of the study consisted of 178 middle-level managers of large-scale manufacturing in Banten. The result of the study showed that asymmetry information affects budgetary participation and budgetary participation influence on performance through job relevant information. These findings give some inputs to the company's management when the local information from subordinate is more complete than the superior information. Therefore, the company should open enough space to involve subordinates in the budgeting process. By providing the opportunity to participate in the preparation of the budget, local information obtained will be taken into consideration in deciding the budget.
\end{abstract}

Index Terms-Asymmetry information, budgetary participation, job relevant information, job performance.

\section{INTRODUCTION}

The relationship between budgetary participation and job performance has been widely studied by researchers in management accounting literature. The positive correlation between budgetary participation and job performance has been supported by both experimental and survey research [1].

Previous study notes that if the reason for the organization to give space for the participation of the budget is to share information between superiors and subordinates, the asymmetry information is estimated to superiors and subordinates as antecedents of budgetary participation. Asymmetry information can be used as an antecedent of budgetary participation in empirical research [2].

The agency theory found that budgetary participation arise because various parties involved in the budgeting process have different information about uncertainty (e.g. branch and central management) [3], [4]. Asymmetry information arises when subordinates have relevant information toward the decision making process of budgeting while the superior does not have enough relevant information [5]. Asymmetry information occurs when one party has an adequate knowledge of the information about the company, while others are not.

Manuscript received April 10, 2013; revised June 04, 2013.

This work was supported in part by Department of Accounting, Sultan Ageng Tirtayasa University (UNTIRTA), and Banten Jaya University (UNBAJA), Serang, Indonesia.

Imam Abu Hanifah is with Accounting Department at Sultan Ageng Tirtayasa University, Indonesia (e-mail: imamabuhanifah@gmail.com).
Shields \& Young [4] have proven that there is a positive relationship between asymmetry information and budgetary participation. Asymmetry information will commonly be going on in a very large company with diverse products and technologies. In such companies, the center management did not know about local conditions experienced by lower-level managers. Central management can use budgetary participation to learn about of the local environment and also provide a good motivation for the underlying managers. Thus, the information held lower-level managers (private information) is the antecedent variable that determines the use of budgetary participation. Shields \& Young [4] proposed a path analysis model to explain the relationship of participation and performance, and argued that asymmetry information will lead to demand budgetary participation and in turn, budgetary participation related to the company performance.

Cognitive mechanism is considered in this budgetary participation research based on the psychological aspect. [6]. Cognitive aspects in budgetary participation provide subordinates the opportunity to share their local and specialized knowledge with their peers and superiors to enhance their job performance [7]. Cognitive aspect used in this study is Job relevant information.

The act of participation provides an opportunity for subordinates to gather, exchange and disseminate job-relevant information (JRI) to enhance their decision making process [6]. Job relevant information aims to facilitate decision-making related to the task. Job relevant information also gave a more accurate prediction of environmental conditions, and can improve performance because it would be more effective in selecting appropriate actions. Champbell and Gingrich provided some evidences that can support positive performance effects of job relevant information and concluded that participation in goal setting was needed more for a complex work than for simpler projects which do not give significant effect on the job performance [8].

The impact of budgetary participation on variety of variables may give different results for developing countries. Some government agencies in Indonesia have conducted the study and concluded that the top management in developing countries is often reluctant to share information with subordinates due to fear of manipulation and misinterpretation of information by their subordinates [9]. This is because many senior managers are politicians and they like to maintain power distance with their subordinates [10].

In other words, other researchers stated that managers in developing countries can participate in the budgeting process 
not because they want to make a meaningful contribution, but simply because of their fear of being punished [11]. This happens because in developing countries, top management often treats employees unfairly due to the lack of recognition/protection of human rights and high unemployment rates.

This study based on the theories and models introduced by Shields \& Shields [2] in examining asymmetry information as antecedent variable of budgetary participation and influence budgetary participation on job performance through job relevant information.

\section{THE STUDY}

\section{A. Basic Subject}

Banten Province is located in strategic area in the Western gate of Java (as node distribution chain of the island of Sumatra to the island of Java and vice versa). Banten province is very close to Sunda strait and nearby with international shipping area that connect West Asia and Asia Pacific and really close to the capital city of Indonesia, Jakarta. Merak is one of the six ports in Java with the highest export volume and value, and is one of the top ten ports in Indonesia with the highest transport volume [12].

Banten Province is an area that is suitable as an industrial area. This can be seen by the eighteen fast growing industrial area in the province, i.e. Balaraja Industrial Park, CCM Balaraja Industrial Estate, Graha Balaraja Production \& Distribution Center, Jababeka Industrial Estate - Cilegon, Industrial \& Warehousing Cikupamas, MGM Integrated Industrial Estate, Krakatau Industrial Estate Cilegon, Langgeng Sahabat Industrial Estate, Millennium Industrial Estate, Modern Cikande Industrial Estate, Nikomas Gemilang Industrial Estate, Pancatama Industrial Estate, Pasar Kemis Industrial Park, Petrochemical Industrial Estate Pancapuri, Samanda Perdana Industrial Estate, Saur Industrial Estate, Techno Park Bumi Serpong Damai, West Tangerang Industrial Estate Cikupa. All are powered by electricity and telecommunication facilities are adequate.

Manufacturing industry as the leading economic sectors has a very important role in most of the development process in Banten province. Value added generated from the manufacturing industry is the largest contribution of the nine economy sectors. The total value of the Gross Regional Domestic Product (GRDP) at current prices by the year 2011 in Banten is $192,218.91$ billion rupiahs where half of it $91,675.16$ billion rupiahs $(47.69 \%)$ comes from Manufacturing sector [13].

Industrial production growth in large and medium-scale of manufacturing in the first quarter of 2012 has reached $3.41 \%$ from the previous quarter, whereas when compared with the previous year (2011) in the first quarter of 2012 has reached $3.76 \%$ from the quarter of the same period in the previous year (first quarter of 2011) [13].

The sample of this study are big manufacturing companies in Banten province consisted of domestic companies and foreign companies spread in three areas, such as Tangerang, Serang, and Cilegon. Based on data of BKPMD (Investment Coordinating Board) in Banten Province, by the year 2005 the value of foreign investment from South Korea was $78 \%$ and the rest of the countries are Belgium, China and other Asian countries. Most of the investment is earmarked for basic chemical industry, chemical and pharmaceutical goods (over $90 \%$ ), basic metals $(2 \%$ ) and the rest of them are the leather industry, leather goods and shoes [12].

The purpose of this study is to investigate the effect of the cognitive effects toward budgetary participation and job performance.

\section{1) Asymmetry information}

Asymmetry information is a situation in which the agent (subordinate) has a local or private information is more than information held by the principal (superior) relating to areas of responsibility [14]. Asymmetry information in this study was measured by using a six item questionnaire developed by Dunk [14]. The scale of the response was measured using 5 Likert scale from (1) strongly disagree and (5) strongly agree. The followings are the list of questionnaire:

1) I have got much better information regarding with the activities undertaken in my area of responsibility.

2) I am much more familiar with the input-output relationships inherent in the internal operations of my area of responsibility.

3) I am much more certain of the potential performance of my of responsibility.

4) I am much more familiar technically with the work of my area of responsibility.

5) I am much better able to assess the potential impact on yaour activities of factors external to my area of responsibility.

6) I have a much better understanding of what can be achieved in my area of responsibility.

\section{2) Budgetary participation}

Budgetary participation is the extent to which the involvement and influence of individuals (managers) in determining and budgeting division or subdivision either in periodical and annual. Participation or involvement in the budgeting process is measured using four-item instrument based on the instrument by Vroom and Mann [15]. The scale of the response was measured using 5 Likert scale from (1) strongly disagree and (5) strongly agree.

The followings are the list of the questionnaire:

1) I participate in setting the budgets for my organizational unit.

2) I have the authority to decide the activities necessary to achieve the budgets set for my organizational unit.

3) My opinion is an important factor in executing the budgets for my organizational unit.

4) My organizational unit has the authority and responsibility given by the top-level management to execute the budgets.

\section{3) Job relevant information}

Job relevant information is the availability of information to the effectiveness of job-related decisions [16]. Job relevant information was measured using a five item scale used by Kren [17] and further developed by Leach-Lopez et al. [16]. Job relevant information consists of three questions on a scale of 1 to 5, to "strongly disagree" and "strongly agree".

The followings are the list of the questionnaire:

1) I am always clear about what is necessary to perform well on my job. 
2) I have adequate information to make optimal decisions to accomplish my performance objectives.

3) I am able to obtain the strategic information necessary to evaluate important decision alternatives.

\section{4) Job performance}

Job performance is a record of the results obtained from a particular job function over time [18]. The performance indicator consists of nine items. We asked respondents to rate their achievement on a five-point Likert-type scale ( $1=$ significantly below average; and $5=$ significantly above average) in regard to: planning, investigating, coordinating, evaluating, supervising, staffing, negotiating, and representing. We then assessed the overall achievement scores and responses to the nine items were combined into one construct to represent the organizational unit's performance.

\section{B. Research Methodology}

The research method of the study was the survey method. Data collecting technique was conducted through questionnaires and focus group discussion. By conducting the study, it is hoped that empirical evidence can be obtained to confirm some findings about the relationship of some variables being studied.

The questionnaires were sent to the mid-level managers of manufacturing companies in the Province of Banten. Manufacturing companies were selected as the sample of the study due to Banten province as a center of manufacturing industries in Java is the third largest industrial area and the second-fastest realization of the construction industry in Indonesia.

Based on the data from the Department of Industry and Trade of Banten Province, the number of manufacturing industry by the year 2011 were 2,648 industrial spread in 8 districts. The sheer number and contribution of the manufacturing industry in Banten is expected to provide a comprehensive overview and capable of addressing the problems in this study.

The unit of analysis is the individual managers at the level of the organizational hierarchy, i.e. manufacturing mid-level managers as many as 178 people. The effective rate was $32.6 \%$.

\section{RESULT}

The respondents of this study were $68.5 \%$ male with tenure between 11-20 years (41.6\%). Most respondents hold the position as a mid-level manager in the finance department (33.1\%) between $41-50$ years of age $(51.2 \%)$. The majority of respondents who work in foreign companies were $79 \%$ while those who work at the domestic company were $21 \%$.

\section{A. Asymmetry Information}

The indicators of information asymmetry represented by six questions. Indicator states that subordinates have better information for activities done as much as $95 \%$ approval. Indicator stating subordinates have more familiar technically with the work and have better understanding of what can be achieved was $88 \%$ approval. Other indicators of the three other indicators approval as much as $85 \%, 84 \%$ and $83 \%$. This shows that there has been asymmetry information or subordinates have better information on the environmental responsibilities than superior.

The results of the questionnaire for asymmetry information has the ideal score between 6-30, the average value of 23.98 and the answers are in the high category with Cronbach alpha of 0.635 . This indicates that managers consider information that subordinates have more than the informationacquired by the superior, so the company opened the participation of subordinates in preparing the budgets.

\section{B. Budgetary Participation}

The indicators of budgetary participation represented by four questions. Indicators which states that mid-level managers have the authority and responsibility to execute the approved budget as much as $96 \%$. Indicator of mid-level managers opinion is an important factor in the execution of the budget, as much as $94 \%$ approval. Two other indicators approved by $92 \%$. This suggests that the mid-level managers have been given the authority to execute and be responsible for a budget in the area of responsibility.

The results of the questionnaire for the ideal budgetary participation has reached a score between 4-20, the average value of 17.13 and the answers are in the category of very high with Cronbach alpha of 0.671 . This suggests that budgetary participation is necessary and has been used for budgeting process in the company.

\section{Job Relevant Information}

Indicators of job relevant information represented by three questions. All indicators approval as much as 100\%. Indicators which states that mid-level managers have sufficient information to make optimal decisions in achieving their performance goals, get answers strongly agree $46 \%$ higher than the other two indicators. This suggests that the mid-level managers need strategic information related to job to achieve better performance.

The results of the questionnaire for job relevant information has ideal score between 3-15, the average value of 13.31 and the answers are in the category of very high with Cronbach alpha of 0.616 . Very high category shows that Job relevant information required by the respondents in their work so that respondents can run optimally in taking decisions that then impact on performance.

\section{Job Performance}

Indicators of managerial performance represented by nine questions. All indicators approval as much as $100 \%$. Indicator stating that the overall mid-level manager has a good performance, get answers "significantly above average" as much as $83 \%$ larger than other indicators. Indicator of evaluating, supervising, staffing, negotiating obtain respondents' answers " significantly above average" by more than $50 \%$. While the others get the response " significantly above average" by more than $35 \%$. This suggests that the mid-level managers feel their performance has been good.

The results of the questionnaire for job performance has ideal score between 9-45, the average value of 37.80 and the answers are in the category of very high with Cronbach alpha of 0.712 . Very high category shows that job performance can be perceived by the respondents after they were involved in the budgeting process, and have relevant information relevant to the job. 


\section{DISCUSSION}

This study classifies a hypothesis that there is influence of antecedent variable and intervening variable toward budgetary participation on job performance as a consequence of budgetary participation. The effect of asymmetry information, budgetary participation, job relevant information, and job performance are divided into four hypotheses. Fig. 1 illustrates the results of path analysis.

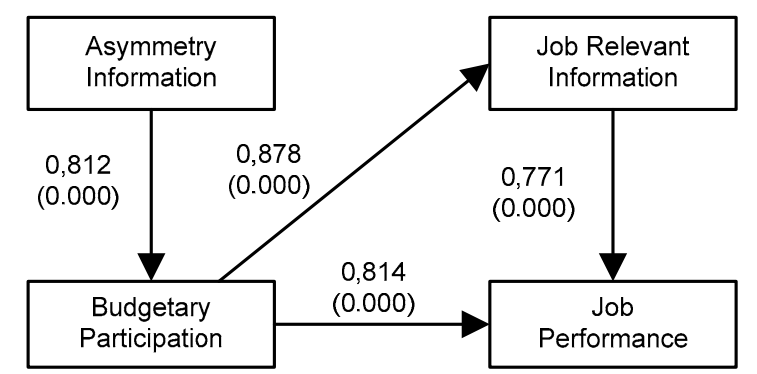

Fig. 1. Structural path coefficients of linking asymmetry information to budgetary participation, job relevant information and job performance.

The first hypothesis assumed that asymmetry information will be positive effect to budgetary participation. Test results yield point value $\mathrm{R}=0.812$ ( $\mathrm{Sig}$. 0.000). The hypothesis proposed empirical support and prove that there has been asymmetry information between superiors and subordinates.

These results indicate that the higher asymmetry information occurs between superior and subordinate, the head of the company should involve the higher mid-level managers in the budgeting process in order to obtain information and a clearer understanding of the private information acquired by subordinate. Private information about local conditions is needed in the budget process.

Subordinates can provide input based on local conditions necessary to make certain assumptions to be used in establishing the budget. Asymmetry information is an important determinant of the need for participation in the budget.

Managers who responded stated that they are more aware of the information that is in the area of responsibility, a better understanding of the technical work, and a better understanding of what can be achieved in an environment of responsibility. Its local information is needed to assess the business opportunities and risks as well as to make the budget more structured sense. Information they have submitted in the form of the work program and the meetings held to establish a plan and a budget.

In many ways, the lack of information indicates a problem of uncertainty for decision-makers. Managers may not know exactly the consequences of the actions to be taken, therefore better information to reduce uncertainty and lead to better decisions.

The second hypothesis showed that there is positive influence of budgetary participation toward job performance. Test results yield point value $\mathrm{R}=0.814$ (Sig. 0.000). This hypothesis is supported by the result of data collecting technique. These results indicate that the higher involvement of mid-level managers in the budgeting process, so it will improve the performance of managers. This is because that by providing the opportunity for subordinates to participate in the preparation of budgets, subordinates may have the opportunity to convey to local conditions, and in order to negotiate more reasonable budget. Thus, the budget set by involving subordinates would lead to a sense of commitment that subordinates would then increase their efforts to achieve budgetary targets and improve their performance.

Majority of survey respondents agreed with the questions asked in the questionnaire. Respondents felt the opportunities presented by the company to participate in the preparation of the budgets. The fourth indicator of budgetary participation i.e. has the authority and responsibility given by the top-level management to execute the budgets, opinions managers is an important factor in executing the budgets, involvement in preparing the budgets, and authority in deciding the activities to get the answers agree and strongly agree more than $90 \%$ of respondents.

The third hypothesis proposed assumed that budgetary participation of a positive effect on Job relevant information. Test results yield point value $\mathrm{R}=0.878$ (Sig. 0.000). This hypothesis can be supported. These results indicate that the higher participation of a given mid-level manager in preparing the budget, then the higher the need for Job relevant information. Involvement in the budget process enables them to deliver local information they have so that they can clarify the information required in performing the job.

The last hypothesis, job relevant information (JRI) has a positive effect on job performance. Test results yield point value $\mathrm{R}=0.771$ (Sig. 0.000). This hypothesis can be accepted and supported by the research findings.

These results indicate that the information is relevant to the job are needed by mid-level managers to improve performance. Availability of information related to the tasks that the duty of the managers will be improve investigation and coordination by managers to achieve those objectives. Job relevant information allows managers to look for approaches that are used for the task, and will make the managers try to work harder and more vibrant when compared with managers who do not have enough information related to the job.

\section{CONCLUSION}

Based on the results of the study, it can be concluded that relationship between budgetary participation and job performance affect cognitive aspects, that is as assimetry and JRI. Subordinate acquired his own environment which became his responsibilities, and also acquired relationship of input-output in the internal of the companies. Therefore, subordinate has enough decision toward the optimum decision in order to reach performance goals.

The results provide sufficient evidence to support the agency theory. These results provide a strong explanation that personal information (private) owned by mid-level managers are indispensable in the preparation of the budget for the company to adapt to the business environment. It is necessary to involve mid-level managers in the preparation of the company's budget.

These results also provide a strong explanation that ties budgetary participation and managerial performance is mediated by job relevant information. Subordinate participation in budget formulation proven to improve its business environment to predict and set his sights on 
decisions and behaviors needed in the future. Thus the budgetary participation and job relevant information will improve performance.

Most manufacturing company in Banten province owned by foreign respondents and they have a very wide span of control. This condition allows information problem, either in bureaucratic procedures and also the problem of cultural and language gap. This is an issue that is often found in developing countries. These findings may also occur in other developing countries, such as in Asia which have foreign companies.

This study has some weaknesses that should be noted that is not able to detect which indicators are most responsible form of research variables. This is likely to affect the relationship between variables. For the next study, it should consider the use of SEM (structural equation modeling) analysis in order to know the indicators that have a strong influence in crating the research variables.

\section{ACKNOWLEDGMENT}

We would like to express our gratitude to Diponegoro University, Sultan Ageng Tirtayasa University, and Banten Jaya University for the informational supports; also managers of manufacturing companies in Banten province, Indonesia.

\section{REFERENCES}

[1] M. A. Leach-López, W. W. Stammerjohan, and K. S. Lee, "Budget Participation and job performance of South Korean managers mediated by job satisfaction and job relevant information," Management Research News, vol. 32, no. 3, pp. 220-238, 2009.

[2] J. F. Shield and M. D. Shields, "Antecedents of participative budgeting," Accounting, Organizations and Society, vol. 23, no. 1, pp. 49-76, 1998.

[3] A. Kirby, S. Reicheistein, P. Sen, and T. Paik, "Participation, Slack, and Budget-Based Performance Evaluation," Journal of Accounting Research, pp. 109-128, 1991.

[4] M. D. Shields and S. M. Young, "Antecedents and consequences of partisipative budgeting: evidence on the effects of asymmetrical information," Journal of Management Accounting Research, vol. 5, pp. 265-280, 1993.

[5] J. H. Evans, R. L. Hannan, R. Krishnan, and D. V. Moser, "Honesty in managerial reporting," The Accounting Review, vol. 76, no. 4, pp. 537-559, 2001.

[6] V. K. Chong and K. M. Chong, "Budget Goal Commitment and Informational Effects of Budget participation on Performance: A
Structural Equation Modeling Approach," Behavioral Research in Accounting, vol. 14, pp. 65-86, 2002.

[7] V. K. Chong, I. R. C. Eggleton, and M. K. C. Leong, "The multiple roles of participative budgeting on job performance," Advances in Accounting, vol. 22, pp. 67-95, 2006.

[8] D. J. Champbell and K. F. Gingrich, "The interactive effects of task complexity and participation on task performance: A field experiment," Organizational Behavior and Human Decision Processes, vol. 38 , pp. 162-80, 1986.

[9] J. Jermias and T. Setiawan, "The moderating effects of hierarchy and control systems on the relationship between budgetary participation and performance," The International Journal of Accounting, vol. 43, pp. 268-292, 2008.

[10] M. Alam, "Budgetary process in uncertain contexts: A study of state owned enterprises in Bangladesh," Management Accounting Research, vol. 8, pp. 147-168, 1997.

[11] S. Uddin and T. Hopper, "A Bangladesh soap opera: Privatization, accounting and regimes of control in a less developed country,' Accounting Organizations and Society, vol. 26, pp. 643-672, 2001.

[12] P. Banten, "Evaluasi tiga tahun pelaksanaan RPJMN 2004-2009 di Provinsi Banten," pp. 85-86, 2008.

[13] B. P. S. P. Banten, "Pertumbuhan Produksi Industri Manufaktur Triwulan I Tahun 2012," Berita Resmi Statistik, vol. 20, pp. 1-9, 2012.

[14] A. S. Dunk, "The effect of budget emphasis and information asymmetry on the relation between budgetary participation and slack," The Accounting Review, vol. 68, no. 2, pp. 400-410, 1993.

[15] V. H. Vroom and F. C. Mann, "Leader authoritarianism and employee attitudes," Personnel Psychology, vol. 13, pp. 125-140, 1960.

[16] M. A. Leach-Lopez, W. W. Stammerjohan, and F. M. McNair, "Differences in the Role of Job-Relevant Information in the Budget Participation-Performance Relationship among U.S. and Mexican Managers: A Question of Culture or Communication," Journal of Management Accounting Research, vol. 19, pp. 105-136, 2007.

[17] L. Kren, "Budgetary participation and managerial performance: The impact of information and environmental volatility," The Accounting Review, vol. 67, no. 3, pp. 511-526, 1992.

[18] S. Williams, "The effects of distributive and procedural justice on performance," The Journal of Psychology, vol. 133, no. 2, pp. 183-193, 1999.

[19] T. A. Mahoney, T. H. Jerdee, and S. J. Carroll, Development of Managerial Performance: A Research Approach, Cincinnati, $\mathrm{OH}$ : Southwestern Publishing Company, 1963.

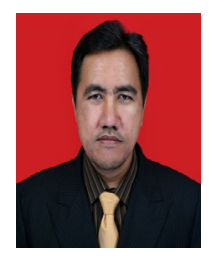

Imam Abu Hanifah was born in Serang, Indonesia on May 26, 1973. His educational background includes: undergraduate at Padjadjaran University, Bandung, 1998 and graduate program in the same place in 2002 Currently completing $\mathrm{Ph} . \mathrm{D}$ program at Diponegoro University, Semarang, Indonesia. The major field of study is management accounting. He is a lecturer in Departement of Accounting, Sultan Ageng Tirtayasa University and Banten Jaya University, Serang, Banten, Indonesia and this is the current job of him. 